\title{
Üriner Sistem Enfeksiyonu Olan Gebelerde Nötrofil-Lenfosit Oranının Tedaviye Dirençli Hastaları Tahmin Etmede ve Tedavinin Takibindeki Rolü
}

\author{
The Role of Neutrophil-lymphocyte Rate in Treatment Resistant Patients in Treatments With \\ Urinary Tract Infection
}

\author{
Ergün Alma', Hakan Erçil', Adem Altunkol', Güçlü Gürlen', Ediz Vurușkan', Onur Küçüktopçu², Zafer Gökhan Gürbüz' \\ 1 Sağlık Bilimleri Üniversitesi, Adana Șehir Eğitim ve Araștırma Hastanesi, Üroloji Kliniği, Yüreğir, Adana \\ 2 Kulu Devlet Hastanesi, Üroloji Kliniği, Kulu, Konya
}

Geliş tarihi (Submitted): 14.09.2019 Kabul tarihi (Accepted): 18.12.2019

Yazışma / Correspondence Dr. Ergün Alma, FEBU Sağlık Bilimleri Üniversitesi, Adana Şehir Eğitim ve Araştırma Hastanesi, Üroloji Kliniği, Yüreğir, Adana Tel: +905057596371

E-mail: almaerim@yahoo.com

\section{ORCID}

E.A. 0000-0003-2633-5274 H.E. 0000-0001-8925-4637 A.A. 0000-0002-9300-3694 G.G. 0000-0002-7830-5010 E.V. 0000-0002-3446-0430 O.K. 0000-0002-5609-8735 Z.G.G. 0000-0002-7325-1965

\section{(1) (8)}

Bu eser Creative Commons AtıfGayriTicari 4.0 Uluslararası Lisans ile lisanslanmıstır.
Özet

Giriș: Üriner sistem enfeksiyonu (ÜSE) olan gebelerde nötrofil lenfosit oranının (NLO) tedaviye direnç ve takipteki rolünü değerlendirmek.

Gereç ve Yöntemler: Eylül 2016-Aralık 2018 tarihleri arasında ÜSE şikayetleri ile başvuran 88 gebenin kayıtları retrospektif olarak incelendi. Etyolojiyi daha da komplike hale getiren taş hastalığı, JJ stent ya da nefrostomi yerleştirilmesi, üriner sistem anatomik malformasyonu olan hastalar çalışmadan dışlandı. Hastalar ilk ve üçüncü günkü medikal tedavisine göre iki gruba ayrılarak değerlendirildi.

Bulgular: Grup A'da yaş ortalaması $23,7 \pm 4,7$ olan 64 hasta ve grup B' de $24,4 \pm 6,0$ olan 24 hastadan oluşmaktaydı. İlk başvuruda NLO ortalamasi grup A'da $4,7 \pm 1,2$ ve grup B'de 7,1 $\pm 1,9$ idi. Grup B de ampirik tedavi sonrası 3 . günde bu değer $6,7 \pm 2,1$ idi ve aradaki farklılık istatistiksel olarak anlamlı değildi ( $p>0,05)$. Tedavi süreci sonunda grup A da NLO ortalamas $2,4 \pm 1,0$ 'a gerilerken, grup $B^{\prime}$ de ise $1,4 \pm 0,6$ düzeyine gerilemiști $(\mathrm{p}<0,05)$

NLO için kestirim değeri 6,15 olarak belirlendi (Duyarllık 0,76, özgüllük 0,86 ve $\mathrm{p}<0,001)$. Tüm hastalar bu kestirim değerine göre tekrar karşlaştırıldığında ilk başvuruda grup A' da $9(\% 14)$ ve grup B de $19(\% 79,1)$ hasta bu değerin üzerinde NLO seviyesine sahipti $(\boldsymbol{p}<0.001)$

Sonuç: NLO hem tedaviye dirençli hasta grubunun belirlenmesinde hem de tedaviye yanıtın izlenmesinde klinisyene yararlı olabilecek bir belirteçtir.

Anahtar Kelimeler: Üriner sistem enfeksiyonu; Nötrofil lenfosit oranı; Gebe
Abstract

Objective: To evaluate the role of neutrophil-lymphocyte ratio in treatment resistance and follow-up in pregnant women with lower urinary tract infection.

Materials and Methods: The data of 88 pregnant women with UTI complaints between September 2016 and December 2018 were retrospectively reviewed. Patients with stone disease, JJ stent or nephrostomy placement, and urinary system anatomic malformation that complicate the etiology were excluded from the study. Patients were divided into two groups according to their first and third day medical treatment.

Results: Group A consisted of 64 patients with a mean age of $23.7 \pm 4.7$ years and group B consisted of 24 patients with $24.4 \pm 6.0$ years. The mean NLR at the first visit was $4.7 \pm 1.2$ in group A and $7.1 \pm 1.9$ in group B. In group B, this value was $6.7 \pm 2.1$ on the third day after empirical treatment and the difference was not statistically significant ( $p>0.05)$. At the end of the treatment period, the mean NLR in group A decreased to $2.4 \pm 1.0$, and it decreased to 1.4 \pm 0.6 in group $\mathrm{B}(\mathrm{P}<0.05)$. The cutoff value for NLR was 6.15 (sensitivity 0.76 , specificity 0.86 , and $\mathrm{P}<0.001$ ). When all patients were compared according to this cutoff value, 9 (14\%) and 19 (79.1\%) patients in group A had NLR levels above this value at the first admission (P $<0.001)$.

Conclusion: NLR is a marker that can be useful to the clinician both in determining the treatment-resistant patient group and in following the response to treatment.

Keywords: Urinary tract infection; Neutrophil-lymphocyte ratio; Pregnant 


\section{GiRiş}

Gebelik esnasında oluşan bazı anatomik, hormonal ve fonksiyonel değişiklikler nedeni ile üriner sistem enfeksiyonuna (ÜSE) yatkınlık artmakta ve bu hastaların uygun şekilde tedavi edilmesi önerilmektedir $(1,2)$. Gebelerdeki ÜSE komplike olarak kabul edilmekte ve uygun şekilde tedavi edilmeyen ÜSE ise preterm eylem, erken membran rüptürü, koryoamniyonitis, neonatal enfeksiyon ve düşük doğum ağırlığı gibi daha ciddi bazı sonuçlara yol açabilmektedir (3). ÜSE için risk faktörleri mevcut olan gebelerin ilk başvurusunda mutlaka idrar kültür-antibiyogram çalışması önerilmektedir (4). ÜSE tanısında idrar tetkiki ve kültür-antibiyogram standart olmakla beraber bu sürecin tamamının 3-4 gün civarında zaman alması teşhis için daha hızlı, ucuz, güvenilir ve klinikte kolay uygulanabilir tanı metotlarının geliştirilmesini zorunlu kılmaktadır. $\mathrm{Bu}$ metotların tedaviye dirençli enfeksiyonları öngörebilmesi ve tedaviye olan cevabı da değerlendirmesi metodu daha kullanışlı hale getirmektedir. ÜSE tanısı için tanımlanmış bazı yöntemler ise uygulama, ulaşım zorluğu ve maliyet gibi bazı nedenlerden dolayı klinikte yaygın kullanım görememişlerdir(5).

Nötrofil-lenfosit oranının (NLO) hızlı ve kolay ulaşılabilir bir enflamasyon belirtecidir ve farklı klinik durumlarda bu özelliği gösterilmiştir (6,7). Özellikle nötrofiller immün yanıtta son derece öneme sahiptir ve enfeksiyonun erken döneminde NLO'da değişiklikler meydana gelmektedir (8). ÜSE'de semptomlar ve idrar tetkiki bulguları tanı için yönlendirici olsa da kesin tanı çoğu için gerekli olan idrar kültürü zaman alması hızlı tanı yöntemlerine olan ihtiyacı artırmaktadır. Gebelerde uygun tedaviye zaman kaybedilmeden başlanması çok önemlidir ve NLO'nun gebedeki ÜSE'de kullanılabilirliğini gösteren çalışmalar son derece yetersizdir. Bu çalışma ile ÜSE olan gebelerde NLO’nun bir enflamasyon parametresi olarak kullanılabilirliğinin araştırılması amaçlanmıştır.

\section{GEREÇ VE YÖNTEM}

Eylül 2016-Aralık 2018 tarihleri arasında kliniğimize idrarda yanma, sık idrara çıkma, yan ağrısı, ateş, halsizlik gibi ÜSE bulguları ile başvuran gebelerin kayıtları retrospektif olarak incelendi. ÜSE'yi daha da komplike hale getirecek olan ve abdominopelvik ultrasonografi (USG) ile etyolojik sebebin net olarak ayrılamayabileceği üriner sistem taş hastalı̆̆ı, hidroüreteronefroz, üreteral JJ stent ya da perkütan nefrostomi varlığı ile üriner sistem anatomik anomalisi (malrotasyon, ektopi, at nalı vs) saptanan hastalar çalışma dışı bırakıldı. Hastalar öncelikle idrar tetkiki, idrar kültür-antibiyogramı, tam kan sayımı, C-reaktif protein (CRP) ve abdominopelvik ultrasonografi (USG) tetkikleri değerlendirildi. Hastanın klinik şikayetlerine ek olarak idrar tetkikinde mikroskobik incelemede her sahada 5 ve üzerinde lökositüri, nitrit varlığı ve lökosit esteraz pozitifliği üriner enfeksiyon ön tanısı için yeterli kriterler olarak değerlendirildi. Bu hastalardan usg ve tam kan analizi ve idrar tetkiki sonuçlarına göre ve klinik bulguları ayaktan tedaviye uygun olan hastalara idrar kültürü sonuçlanıncaya kadar ampirik antibiyotik olarak ikinci kuşak oral sefalosporin (sefiksim $400 \mathrm{mg}$ ) tedavisi başlanıldı. Hastalar üçüncü gün kontrollerinde idrar kültürü sonuçları ve semptomlarına göre tekrar değerlendirilerek iki gruba ayrıldı. İlk günkü semptomlarına yönelik başlanılan tedavi ile klinik bulgularında düzelme olan ve idrar kültürü sonuçları uygun olan ya da idrar kültürü uygun olmayan ancak klinik bulgularında bozulma olmayan hastalarda ayaktan tedaviye devam edildi (Grup A). İlk günkü semptomlarına göre klinik bulgularında düzelme olmayan, idrar kültürü sonuçları uyumsuz olan ve klinik bulguları bozulan hastalar ile ilk gün semptomları nedeni ile ayaktan tedavi edilemeyecek olan hastalar ise hospitalize edilerek tedavi edilmişti (Grup B). Tedavi sonunda tüm hastalardan idrar kültürü, tam kan sayımı ve CRP tekrarı yapıldı. Klinik bulguları ile beraber bu parametrelerde normalize olan hastalarda tedavi başarılı olarak değerlendirildi.

\section{İstatistiksel Analiz}

İstatistiksel değerlendirme için R3.3.1 paket programı kullanıldı. Veriler sayı, ortalama ve standart sapma olarak değerlendirildi. Sayıların karşılaştırılmasında Ki kare testi kullanıldı. Ortalamaların karşılaştırılacağ 1 verilere homojenite testi yapıldı. Homojen dağılım gösterenler değerlerin karşılaştırılmasında Stu- 
Tablo 1:Demografikler ve enfeksiyon parametreleri

\begin{tabular}{|c|c|c|c|c|}
\hline \multicolumn{2}{|l|}{ Değiş̧kenler } & Grup A & Grup B & $p$ \\
\hline \multicolumn{2}{|l|}{ Yaş } & $23,7 \pm 4,7$ & $24,4 \pm 6,0$ & 0,55 \\
\hline \multicolumn{2}{|c|}{ Gestasyonel Hafta } & $24,2 \pm 5,7$ & $26,7 \pm 5,8$ & 0,07 \\
\hline \multicolumn{2}{|c|}{ Kaçıncı Gebelik } & $1,7 \pm 0,8$ & $1,7 \pm 1,1$ & 0,98 \\
\hline \multicolumn{2}{|l|}{ NLO 1} & $4,7 \pm 1,2$ & $7,1 \pm 1,9$ & $<0,001$ \\
\hline \multicolumn{2}{|l|}{ NLO 2} & $2,4 \pm 1,0$ & $1,4 \pm 0,6$ & $<0,001$ \\
\hline \multicolumn{2}{|l|}{ CRP 1} & $3,0 \pm 3,0$ & $5,6 \pm 2,1$ & $<0,001$ \\
\hline \multicolumn{2}{|l|}{ CRP 2} & $1,3 \pm 1,7$ & $1,2 \pm 1,0$ & 0,66 \\
\hline \multicolumn{2}{|l|}{ WBC 1} & $11572 \pm 2771$ & $12606 \pm 3301$ & 0,14 \\
\hline \multicolumn{2}{|l|}{ WBC 2} & $9433 \pm 1871$ & $9338 \pm 2016$ & 0,83 \\
\hline \multirow{4}{*}{ İdrar Kültürü } & Üreme yok & 45 & 12 & \multirow{4}{*}{0,07} \\
\hline & E.C. & 11 & 10 & \\
\hline & K.P. & 6 & 1 & \\
\hline & P.M & 2 & 2 & \\
\hline \multirow{2}{*}{ Ateş } & Yok & 51 & 14 & \multirow{2}{*}{0,04} \\
\hline & Var & 13 & 10 & \\
\hline
\end{tabular}

NLO1-CRP1-WBC1:Tedavi öncesi değerler

NLO2-CRP2-WBC2:Tedavi sonrası değerler

E.C: Escherichia Coli

K.P: Klebsiella Pneumoniae

P.M: Proteus Mirabilis

dent $\mathrm{T}$ testi ve diğerlerinin karşılaştırılmasında Mann Whitney U testi kullanıldı. Kestirim değeri tespiti için ROC eğri analizi yapıldı. P değeri $<0,05$ olduğunda karşılaştırılan gruplar arasındaki farklılıklar istatistiksel olarak anlamlı kabul edildi.

\section{BULGULAR}

Çalışmamız grup A'da yaş ortalaması $23.7 \pm 4.7$ olan 64 hasta ve grup B'de ise $24,4 \pm 6,0$ olan 24 hastadan oluşmaktayd. Grup A da ortalama gestasyonel hafta $24,2 \pm 5,7$ iken grup B'de ise 26,7 $\pm 5,8$ idi. Grup A'da ilk başvuru esnasında CRP ve lökosit ortalamaları sırasıyla $4,0 \pm 4,6$ ve $11572 \pm 2,7$ iken bu oranlar grup B'de 4,7 $\pm 2,1$ ve $12606 \pm 3,2$ idi. Tedavi sonrası ise bu değerler grup A'da 1,5 $\pm 2,0$ ve $9433 \pm 1,8$ iken grup B'de 1,4 4 1,6 ve $9338+2,0$ idi. Her iki grup arasında tedavi öncesi ve sonrasındaki CRP ve lökosit değerleri arasında istatistiksel anlamlı farklılık bulunmuyordu $(\boldsymbol{p}>0,05)$. Grup A'da ilk başvuru esnasında 13 hastada (\%20) 38 derece ve üzeri ateş mevcut iken, grup B'de ise 10 hastada $(\% 41,6)$ ateş vardı ve gruplar arasındaki bu farklılık istatistiksel olarak anlamlı idi $(\boldsymbol{p}<0,05)$.
İlk başvuru esnasında NLO ortalaması grup A'da $4,7 \pm 1,2$ iken grup B'de ise 7,1 $\pm 1,9$ idi. Grup B'de ampirik tedavi sonrası 3. günde bu değer $6,7 \pm 2,1$ idi ve aradaki farklılık istatistiksel olarak anlamlı değildi $(\boldsymbol{p}>0,05)$. Tedavi süreci sonunda grup $A^{\prime} d a$ NLO ortalaması 2,4 $\pm 1,0$ 'a gerilerken, grup $B^{\prime}$ de ise $1,4 \pm 0,6$ düzeyine gerilemişti $(\boldsymbol{p}<0,05)$. İki grup arasında yaş ve gebelik haftası ortalamaları arasında ise istatistiksel anlamlı farklılık saptanmadı $(\boldsymbol{p}>0,05)$. Demografikler, tedavi öncesi ve sonrasina ait parametreler tablo l'de gösterilmektedir.

NLO için kestirim değeri 6,15 olarak belirlendi (duyarlılık 0,76, özgüllük 0,86 ve $p<0,001$ ). Tüm hastalar bu kestirim değerine göre tekrar karşılaştırıldığında ilk başvuru esnasında grup A'da 9 (\%14) hasta ve grup B'de ise $19(\% 79,1)$ hastanın bu değerin üzerinde NLO seviyesine sahip olduğu izlendi ve aradaki farklılık istatistiksel olarak anlamlı bulundu $(\boldsymbol{p}<0.001)$. İlk başvuru esnasında idrar kültüründe üreme olan hastalardan 13 (\%14,7)'ünde NLO kestirim değerinin üzerinde idi. CRP ve tam kan sayımındaki lökosit değerleri kestirim 
Tablo 2: Kestirim değerine göre parametreler

\begin{tabular}{|c|c|c|c|c|}
\hline \multicolumn{2}{|c|}{ Değişkenler (kestirim) } & $<6,15$ & $\geq 6,15$ & $P$ \\
\hline \multicolumn{2}{|l|}{ CRP 1} & $3,0 \pm 2,6$ & $5,3 \pm 3,2$ & $<0,001$ \\
\hline \multicolumn{2}{|l|}{ CRP 2} & $1,2 \pm 1,5$ & $1,5 \pm 1,6$ & ,421 \\
\hline \multicolumn{2}{|l|}{ WBC 1} & $11325 \pm 2801$ & $13035 \pm 2966$ & ,010 \\
\hline \multicolumn{2}{|l|}{ WBC 2} & $9157 \pm 1727$ & $9950 \pm 2170$ & ,068 \\
\hline \multirow{2}{*}{ Grup } & A & 55 & 9 & \multirow{2}{*}{$<0,001$} \\
\hline & B & 5 & 19 & \\
\hline \multirow{4}{*}{ İdrar Kültürü } & Üreme yok & 42 & 15 & \multirow{4}{*}{0,184} \\
\hline & E.C. & 10 & 10 & \\
\hline & K.P. & 6 & 1 & \\
\hline & P.M. & 2 & 2 & \\
\hline
\end{tabular}

düzeyine göre incelendiğinde her iki parametre içinde ortalama değerler istatistiksel olarak anlamlı bulundu $(\boldsymbol{p}<0.05)$. Kestirim değerine göre karşılaştırma parametreleri tablo 2'de ve ROC eğri analizi ise figür 1'de gösterilmektedir.

\section{TARTIŞMA}

Gebelik esnasında kadınların yaklaşık \%5-10'unda ÜSE gelişmekte ve bu hasta grubunda tüm hastaneye yatışların yaklaşık \%5’i bu sebepten olmaktadır (9). Gebelik boyunca mesane kapasitesinde artış, üriner staz ve glomerüler filtrasyon oranındaki artış nedeniyle de antibiyotikler idrarda yeterli konsantrasyona ulaşamayabilir ve gebede ÜSE'na olan yatkınlık artar.

ÜSE'de idrar kültürü ve antibiyogram, mikroorganizmanın tespiti ve uygun antibiyotik seçimi için altın standart olmasına rağmen ortalama 2-3 günde sonuçlanması tedavi sürecinin gecikmesine neden olabilmektedir. NLO ise kısa sürede sonuçlanan, ucuz ve ulaşılması kolay bir tetkiktir. NLO birçok farklı klinik durumda enflamasyon belirteci olarak kullanılmış ve farklı kestirim değerleri çeşitli çalışmalarda tanımlanmıştır (10). Azab ve arkadaşları yetişkinlerde ırka göre ulusal değerleri kullanarak yaptıkları araştırmalarında NLO için ortalama kestirim değerini 2,15 olarak belirtirken sigara içiciliği ve artan vücut kitle indeksinin NLO' de farklılıklar yaratabileceğini bildirmişlerdir (11). Forget ve arkadaşları da geriatrik olmayan sağlıklı yetişkinlerde NLO seviyelerinin 0,78 ile 3,53 arasında olduğunu bildirmişlerdir (12). Terradas ve arkadaşları ise bakteriyemili hastalarda NLO’nın bağımsız bir ön- görüsel belirteç olabileceğini ve 7’nin üzerindeki NLO değerlerinin mortalite riskinde artış ile ilişkili olabileceğini belirtmişlerdir (13). NLO’nun değerlendirildiği sağlıklı yetişkinler, malignensi hastaları ve farklı enfeksiyon durumlarında kestirim değerlerinin farklı bulunması enflamasyonun derecesi ile doğru orantılı olarak değişmektedir. Bizim çalışmamızdaki ÜSE olan gebe hastalarda ortalama kestirim değeri 6,15 olarak bulunmuştur. Ancak enflamasyonun yanısıra gebeliğin kendisinin NLO ortalamasını ne kadar etkilediği ise net olarak belli değildir ve bu konuda yapılacak çalışmalar daha aydınlatıcı olabilir.

Bizim çalışmamız da NLO için kestirim değeri 6,15 (duyarlılık 0,76, özgüllük 0,86, $\boldsymbol{p}<0,001$ ) olarak belirlendi ve grup B'de hastaların \%79,1'inde başlangıç değeri bu kestirim değerinin üzerindeydi. Her iki grup birlikte değerlendirildiğinde ise bu oran \%31,8 idi ve bu hastaların \%67,8 'i grup B'de yer alan başlangıç ampirik antibiyotiğe klinik yanıt vermeyen hastalardan oluşmaktaydı. Bu hastaların idrar kültürü sonuçları da kestirim değerine göre gruplandırıldığ zaman aralarında istatistiksel olarak anlamlı farklılık bulunmuyordu $(\boldsymbol{p}>0.05)$. Bu hastalar uygun antibiyotik tedavisi ile hem NLO seviyeleri gerilemiş hem de klinik göstergeleri dramatik şekilde düzelme göstermişti. Bu manada biz NLO'nın tedaviye dirençli olabilecek hastaların önceden tahmin edilmesinde ve tedaviye olan cevabın takip edilmesinde faydalı bir belirteç olabileceğini düşünüyoruz. Bizim verilerimize göre 6,15 'in üzerinde NLO düzeyi olan ÜSE'lu gebe hasta- 


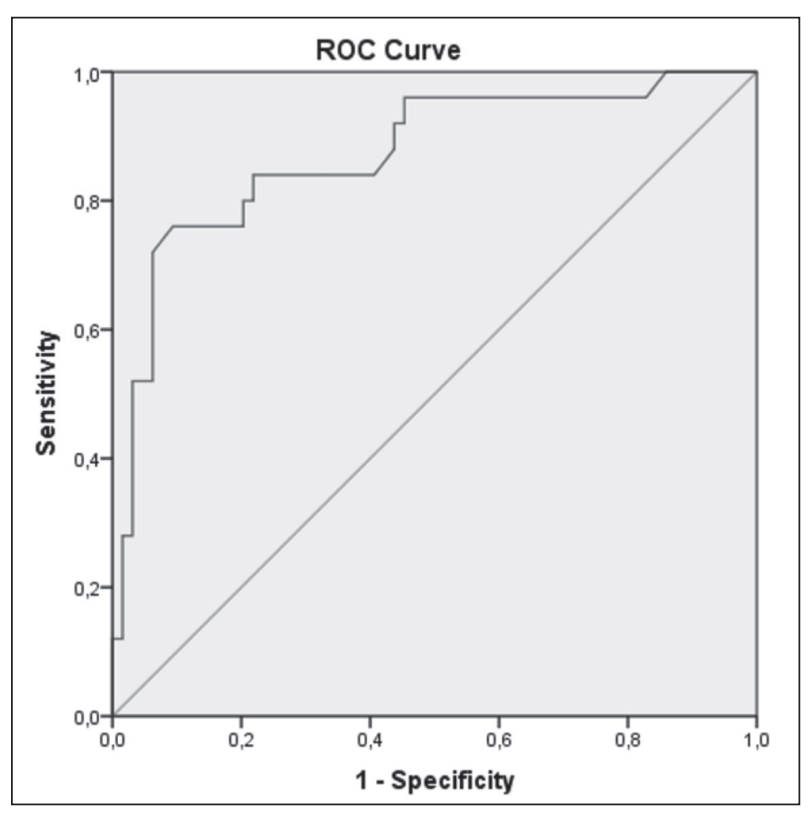

Figür 1: ROC eğri analizi (duyarlılık 0,76 , özgüllük $0,86, p<0,001$ )

larda antibiyotik seçimi yaparken daha dikkatli olunmalı ve bu hasta grubunun belki de yatırılarak tedaviye uygun olabileceği de akılda tutulmalıdır.

ÜSE olan kadınlarda idrar kültür-antibiyogramına ek olarak tam kan sayımında lökositoz ve CRP artışı gibi enfeksiyon parametreleri de değişmektedir. NLO üriner sistem mukozası enfekte olduğunda akut dönemde klinisyene enflamasyonun şiddetini gösterebilmektedir. Han ve arkadaşları febril ÜSE olan genç çocuklarda NLO’nun DMSA defektleri ile korele olduguunu göstermişler ve dahası NLO'nun vezikoüreteral reflünün tahmininde uygun bir marker olabileceğini bildirmişlerdir (14). Gürol ve arkadaşları NLO kestirim değerinin $\geq 5$ olduğu durumlarda, bakteriyel enfeksiyonu tespit etme yeteneğinin daha uygun olması nedeni ile NLO'nun CRP'den daha uygun bir belirteç olduğunu bildirmişlerdir ve sepsiste NLO azalması ya da normale dönmesinin klinik gerileme ile uyumlu olduğunu bildirmişlerdir (15). Bizim çalışmamızda NLO kestirim değeri $\geq 6,15$ olan hastalarda CRP ve lökosit düzeyleri, $<6,15$ olan hastalardan daha yüksek idi ve tedavi ile beraber NLO düzeylerindeki azalmalar CRP ve lökositteki azalma ile de uyumlu idi. Tedavi sonunda her iki grupta da NLO ve diğer enfeksiyon parametreleri gerilemişti. Bu anlamda NLO kolay ulaşılabilir tam kan sayımı ile tedaviye cevabın takibinde de uygun bir alternatif olabilir fakat bizim çalışmamızın küçük bir hasta popülasyonunu göstermesi bakımından daha kapsamlı çalışmalar ile bu hipotezin desteklenmesine gereksinim olduğu da açıktır.

Çalışmamızın bazı limitasyonları bulunmaktadır. Bunlardan en önemlisi retrospektif dizaynlı olması olarak görünmekle beraber küçük bir hasta grubunu kapsaması ve tek merkezin deneyimini yansitması da diğer sınırlandırmalardır. Ancak klinisyenlerin rutin pratiklerinde bu hasta grubu ile sık olarak karşılaştıkları hesaba katıldığı zaman, NLO'nun hem tedaviye dirençli hastaları tahmin edebilme hem de tedavinin takibine odaklı çalışmamızın değerli olabileceğini düşünmekteyiz ve bizim bilgilerimize göre çalışmamız bu konuda literatürde yapılmış olan ilk çalışmalar arasındadir.

Sonuç olarak; NLO üriner sistem enfeksiyonu olan gebe hastalarda tedaviye dirençli olabilecek hasta grubunun tahmin edilmesinde ve tedavinin takibinde klinisyene faydalı olabilecek bir markerdir.

Çıkar Çatışması: Yazarlar arasında araştırmanın doğrudan uygulamalarından kaynaklanan herhangi bir çıkar çatışması bulunmamaktadır.

\section{KAYNAKLAR}

1. Mittal P, Wing DA. Urinary tract infections in pregnancy. Clinics in Perinatology 2005; 32:749-764.

2. Jeyabalan A, Lain KY. Anatomic and functional changes of the upper urinary tract during pregnancy. The Urologic Clinics of North America 2007; 34:1-6.

3. Kalinderi K, Delkos D, Kalinderis M, Athanasiadis A, Kalogiannidis I. Urinary tract infection during pregnancy: current concepts on a common multifaceted problem. J Obstet Gynaecol. 2018; 38: 448-453.

4. Ovalle A, Levancini M. Urinary tract infections in pregnancy. Curr Opin Urol 2001; 11: 55-9.

5. Ota Y, Furuhashi K, Nanba T, Yamanaka K, Ishikawa J, Nagura O, Hamada E, Maekawa M.A rapid and simple detection method for phenotypic antimicrobial resistance in Escherichia coli by loop-mediated isothermal amplification. J Med Microbiol 2019; 68:169-177.

6. Yoon NB, Son C, Um SJ. Role of the neutrophil-lymphocyte count ratio in the differential diagnosis between pulmonary 
tuberculosis and bacterial community-acquired pneumonia. Ann Lab Med 2013; 33: 105-10.

7. Lowsby R, Gomes C, Jarman I, Lisboa P, Nee PA, Vardhan $\mathrm{M}$, et al. Neutrophil to lymphocyte count ratio as an early indicator of blood stream infection in the emergency department. Emerg Med J 2015; 32: 531-4.

8. Ilhan M, Ilhan G, Gok AF, Bademler S, Verit Atmaca F, Ertekin C. Evaluation of neutrophil-lymphocyte ratio, platelete lymphocyte ratio and red blood cell distribution widthplatelet ratio as early predictor of acute pancreatitis in pregnancy. J Matern Fetal Neonatal Med 2015; 5: 1e5.

9. Szweda H, Jóźwik M. Urinary tract infections during pregnancy - an updated overview. Dev Period Med 2016; 20 : 263-72.

10. Xiao GQ, Liu C, Liu DL, Yang JY, Yan LN. 2013. Neutrophil lymphocyte ratio predicts the prognosis of patients with hepatocellular carcinoma after liver transplantation. World J. Gastroenterol 2013;19: 8398-8407.

11. Azab B, Camacho-Rivera M, Taioli E. Average values and racial differences of neutrophil lymphocyte ratio among a nationally representative sample of United States subjects. PLoS One. 2014; 6: 9:e112361.
12. Forget P, Khalifa C, Defour JP, Latinne D, Van Pel MC, De Kock M. What is the normal value of the neutrophil-tolymphocyte ratio? BMC Res Notes 2017;3:10-12.

13. Terradas R, Grau S, Blanch J, Riu M, Saballs P, Castells X, Horcajada JP, Knobel H. Eosinophil count and neutrophillymphocyte count ratio as prognostic markers in patients with bacteremia: a retrospective cohort study. PLoS One 2012;7:e42860.

14. Han SY, Lee IR, Park SJ, Kim JH, Shin JI. Usefulness of neutrophil-lymphocyte ratio in young children with febrile urinary tract infection. Korean J Pediatr 2016;59:139-44. Gürol G, Çiftci İH, Terizi HA, Atasoy AR, Ozbek A, Köroğlu M. Are there standardized cutoff values for neutrophil-lymphocyte ratios in bacteremia or sepsis? J Microbiol Biotechnol 2015;25:521-5. 